\title{
Lycorine inhibits cell proliferation, migration and invasion, and primarily exerts in vitro cytostatic effects in human colorectal cancer via activating the ROS/p38 and AKT signaling pathways
}

\author{
PING ZHANG ${ }^{1}$, XIAOHUI YUAN ${ }^{2}$, TINGTING YU ${ }^{2}$, HUAKUN HUANG $^{2}$, CHUNMEI YANG $^{2}$, \\ LULU ZHANG ${ }^{2}$, SHENGDONG YANG $^{3}$, XIAOJI LUO ${ }^{3}$ and JINYONG LUO ${ }^{2}$ \\ ${ }^{1}$ Department of Laboratory Medicine, Tianfu New Area People's Hospital, Chengdu, Sichuan 610213; \\ ${ }^{2}$ Key Laboratory of Clinical Laboratory Medical Diagnostics, Ministry of Education, Chongqing Medical University; \\ ${ }^{3}$ Department of Orthopedics, The First Affiliated Hospital of Chongqing Medical University, Chongqing 400016, P.R. China
}

Received June 26, 2020; Accepted December 23, 2020

DOI: $10.3892 /$ or.2021.7970

\begin{abstract}
Colorectal cancer (CRC) is a life-threatening malignant tumor of the digestive tract. Diverse gene mutations and complicated alterations to the signaling pathways in CRC lead to heterogeneity in response to chemotherapy. Moreover, anticancer drugs for CRC chemotherapy are limited due to adverse events. Therefore, developing more effective, tolerable and safe drugs for the treatment of CRC is important. The present study aimed to investigate the effect of lycorine on human CRC cell proliferation, migration, invasion, apoptosis, cell cycle distribution, as well as the underlying molecular mechanism. The crystal violet staining and MTT assay results demonstrated that lycorine suppressed cell proliferation in a dose- and time-dependent manner in the three CRC cell lines, HCT116, LoVo and SW480. Similarly, verified by performing wound healing and Transwell assays, lycorine significantly inhibited HCT116 and LoVo cell migration and invasion in vitro compared with the control group. In LoVo cells, the protein expression levels of matrix metallopeptidases, snail family transcriptional repressor 1 , Vimentin and $\mathrm{N}$-cadherin were significantly downregulated, whereas the protein expression levels of E-cadherin were significantly upregulated by lycorine treatment compared with the control group. The Hoechst 33258 staining and flow cytometry assay results indicated that lycorine mediated its cytostatic effect on CRC cells potentially via
\end{abstract}

Correspondence to: Professor Jinyong Luo, Key Laboratory of Clinical Laboratory Medical Diagnostics, Ministry of Education, Chongqing Medical University, No. 1 Yixueyuan Road, Yuzhong District, Chongqing 400016, P.R. China

E-mail: luojinyong@sina.com

Abbreviations: CRC, colorectal cancer; DCFH-DA, 2',7'-dichlorofluorescein-diacetate; ECM, extracellular matrix; EMT, epithelial-mesenchymal transition; MMP, matrix metallopeptidase; ROS, reactive oxygen species

Key words: lycorine, colorectal cancer cells, cytostasis, ROS/p38, AKT inducing cell cycle arrest, but not apoptosis. Compared with the control group, lycorine significantly induced HCT116 cell cycle arrest at the $\mathrm{G}_{2} / \mathrm{M}$ phase, but significantly induced LoVo cell cycle arrest at the $\mathrm{S}$ and $\mathrm{G}_{2} / \mathrm{M}$ phases. Furthermore, lycorine significantly downregulated the protein expression levels of cyclin D1 and cyclin E1, but significantly increased p21 and Smad4 protein expression levels in HCT116 and LoVo cells compared with the control group. The intracellular reactive oxygen species (ROS) measurement results also indicated that compared with the control group, lycorine significantly induced ROS accumulation, and increased phosphorylated-p38 expression levels and AKT phosphorylation. Collectively, the present study suggested that lycorine might induce cell cycle arrest and exert cytostatic effects potentially via activating ROS/p38 and AKT signaling pathways in CRC cells.

\section{Introduction}

Colorectal cancer (CRC) is one of the most common malignant tumors of the digestive tract worldwide, as the third most frequent malignancy in men and the second in women, and the fourth leading cause of cancer-related death (1). The incidence of CRC is increasing in younger age groups (2). Current treatment strategies for CRC include surgery, radiation and chemotherapy; however, the 5-year survival rate of patients with metastatic CRC is $\sim 10 \%$ (3). Chemotherapy serves an essential role in the treatment of $\mathrm{CRC}$, but CRC is heterogeneous in response to adjuvant chemotherapy (4). Therefore, developing more effective drugs for the treatment of CRC is important.

Lycorine is a natural Amaryllidaceae alkaloid that is extracted from medicinal plants of the Amaryllidaceae family (5). In addition to its analgesic, antibacterial, antifungal, antimalarial and antiviral effects, lycorine also displays antitumor effects against various types of cancer, including multiple myeloma (6), bladder cancer (7) and breast cancer (8), with an $\mathrm{IC}_{50}$ value $<10 \mu \mathrm{mol} / 1$. Moreover, previous studies have reported that lycorine may display relatively lower toxicity against healthy cells (7-9). For example, the $\mathrm{IC}_{50}$ of lycorine in human normal fibroblasts (Wi38, WS1, NHDF cell lines) was $>100 \mu \mathrm{mol} / 1$ (9). The aforementioned studies suggest that 
lycorine may serve as a potentially effective and safe drug candidate for cancer treatment.

In the present study, the effect of lycorine on human CRC cell proliferation, migration, invasion, apoptosis and cell cycle distribution was investigated, and the underlying molecular mechanism was also explored. The results of the present study indicated that due to in vitro cytostatic effects, lycorine might serve as a potential therapeutic for $\mathrm{CRC}$, and the underlying mechanism might be associated with activation of ROS/p38 and AKT signaling, although further investigation is required.

\section{Materials and methods}

Cell lines and cell culture. Human CRC cell lines (LoVo, HCT116 and SW480) were provided by the Key Laboratory of Clinical Laboratory Medical Diagnostics (Ministry of Education, Chongqing Medical University). Cells were cultured in DMEM (HyClone; GE Healthcare Life Sciences) supplemented with 10\% FBS (Shanghai ExCell Biology, Inc.) and $1 \%$ penicillin/streptomycin (HyClone; GE Healthcare Life Sciences) at $37^{\circ} \mathrm{C}$ with $5 \% \mathrm{CO}_{2}$. Lycorine (purity $\geq 98 \%$; Chengdu Ruifensi Biotechnology Co., Ltd.) was dissolved in DMSO (Sigma-Aldrich; Merck KGaA) to a final concentration of $20 \mathrm{mM}$ and stored at $-80^{\circ} \mathrm{C}$.

Crystal violet staining. Cells were seeded into 24-well plates and cultured overnight. At $50 \%$ confluence, cells were treated with different concentrations $(0,1,2,4$ or $8 \mu \mathrm{mol} / \mathrm{l})$ of lycorine at $37^{\circ} \mathrm{C}$ for 24,48 or $72 \mathrm{~h}$. The control group was untreated (0 $\mu \mathrm{mol} / 1$ lycorine) and a $0.4 \%$ DMSO group (treated at $37^{\circ} \mathrm{C}$ for 24,48 or $72 \mathrm{~h}$ ) was also established. At the indicated time point, cells were fixed with $4 \%$ paraformaldehyde at $37^{\circ} \mathrm{C}$ for 20 min and stained with crystal violet (Beyotime Institute of Biotechnology) at room temperature for $5 \mathrm{~min}$. Stained cells were visualized using an Epson Perfection V200 Photo (Epson).

MTT assay. Cells were seeded ( $3 \times 10^{3}$ cells/well) into 96 -well plates overnight. Subsequently, cells were treated with different concentrations $(0,1,2,4$ or $8 \mu \mathrm{mol} / 1)$ of lycorine at $37^{\circ} \mathrm{C}$ for 24 , 48 or $72 \mathrm{~h}$. At the indicated time point, cells were incubated with $5 \mathrm{mg} / \mathrm{ml}$ MTT solution (Sigma-Aldrich; Merck KGaA) at $37^{\circ} \mathrm{C}$ for $4 \mathrm{~h}$. The formazan crystals were dissolved with DMSO (150 $\mu \mathrm{l} /$ well). The absorbance was measured at a wavelength of $490 \mathrm{~nm}$ using a spectrophotometer (Gene Company, Ltd.). Cell viability (\%) was calculated using the following formula: $\left(D_{\text {treatment group }} / D_{\text {control group }}\right) \times 100 \%$, where $D$ represents optical density.

Wound healing assay. Cells were seeded into 6-well plates. At $80-90 \%$ confluence, the cell monolayer was scratched with a $10 \mu \mathrm{l}$ pipette tip and treated with different concentrations $(0,1$, $2,4$ or $8 \mu \mathrm{mol} / 1)$ of lycorine and cultured in DMEM supplemented with $5 \% \mathrm{FBS}$ for 0,12 or $24 \mathrm{~h}$ at $37^{\circ} \mathrm{C}$. The wounds were observed in three randomly selected fields of view using a light microscope (magnification, x100). The wound healing rate $(\%)$ was calculated using the following formula: [ $(0 \mathrm{~h}$ wound width -12 or $24 \mathrm{~h}$ wound width)/0 h wound width] $\mathrm{x} 100$.

Transwell assay. For cell invasion, the 24-well upper chamber (EMD Millipore) was precoated with Matrigel at $37^{\circ} \mathrm{C}$ for
60 min (BD Biosciences). Subsequently, cells were seeded $\left(5 \times 10^{4}\right.$ cells/well) into the upper chamber with serum-free DMEM containing different concentrations $(0,1,2,4$ or $8 \mu \mathrm{mol} / \mathrm{l})$ of lycorine. The lower chamber was filled with DMEM supplemented with $10 \%$ FBS. Following incubation at $37^{\circ} \mathrm{C}$ for $24 \mathrm{~h}$, non-invading cells on the upper surface of the membrane were removed. Invading cells were fixed with $4 \%$ paraformaldehyde at $37^{\circ} \mathrm{C}$ for $20 \mathrm{~min}$ and stained with crystal violet at room temperature for $5 \mathrm{~min}$. Stained cells were visualized using a light microscope (magnification, x100). To assess cell migration, the aforementioned protocol was performed, but the Transwell chambers were not precoated with Matrigel.

Hoechst 33258 staining. Cells were seeded into 24-well plates. At $50 \%$ confluence, cells were treated with different concentrations $(0,1,2,4$ or $8 \mu \mathrm{mol} / \mathrm{l})$ of lycorine at $37^{\circ} \mathrm{C}$ for $24 \mathrm{~h}$. Following fixation with $4 \%$ paraformaldehyde at $37^{\circ} \mathrm{C}$ for $20 \mathrm{~min}$, cells were stained with Hoechst 33258 solution (Beijing Solarbio Science \& Technology Co., Ltd.) for $5 \mathrm{~min}$ at room temperature. Alterations in nuclear morphology were visualized using a fluorescence microscope (magnification, $\mathrm{x} 200$ ). When apoptosis occurs, cell nuclei display enhanced fluorescence intensity due to nuclear fragmentation and chromatin condensation.

Flow cytometry. Cells were plated into $60-\mathrm{mm}$ dishes. At $50 \%$ confluence, cells were treated with different concentrations $(0,1,2,4$ or $8 \mu \mathrm{mol} / \mathrm{l})$ of lycorine at $37^{\circ} \mathrm{C}$ for $24 \mathrm{~h}$. To analyse cell apoptosis including early and late apoptosis, cells were harvested, washed twice with PBS, stained using the Annexin V-FITC/PI kit (Beijing Solarbio Science \& Technology Co., Ltd.), according to the manufacturer's protocol, and analyzed using a flow cytometer (BD Biosciences). To assess cell cycle distribution, cells were re-suspended in $70 \%$ ethanol overnight at $4^{\circ} \mathrm{C}$ for fixation and permeabilisation and stained with PI/RNase Staining Buffer kit (BD Biosciences) according to the manufacturer's protocol. Both cell apoptosis and cell cycle distribution were detected using a CytoFLEX flow cytometer (Beckman Coulter, Inc.) and analysed with FlowJo software (version 10.4.0; BD Biosciences).

Intracellular reactive oxygen species (ROS) measurement. Cells were seeded in 6-well plates. At $50 \%$ confluence, cells were treated with $8 \mu \mathrm{mol} / 1$ lycorine at $37^{\circ} \mathrm{C}$ for 4 or $24 \mathrm{~h}$. Subsequently, cells were incubated with $2^{\prime}, 7^{\prime}$-dichlorofluorescein-diacetate (DCFH-DA; $10 \mu \mathrm{mol} / \mathrm{l}$ ) reagent (Beyotime Institute of Biotechnology) in serum-free DMEM for $30 \mathrm{~min}$ at $37^{\circ} \mathrm{C}$. Following washing three times with $\mathrm{PBS}$, the fluorescence intensity was measured at an excitation wavelength of $488 \mathrm{~nm}$ and an emission wavelength of $525 \mathrm{~nm}$ using a fluorescence plate reader (BioTek Instruments, Inc.). Moreover, following fixation with $4 \%$ paraformaldehyde at $37^{\circ} \mathrm{C}$ for $15 \mathrm{~min}$, cells were stained with DAPI at room temperature for $10 \mathrm{~min}$. Intracellular ROS accumulation, which was assessed using DCFH-DA as aforementioned and nuclear DAPI staining, was visualized using a confocal microscope (magnification, x200).

Western blotting. Cells were seeded into $10-\mathrm{cm}$ dishes. At $50 \%$ confluence, cells were treated with different concentrations of lycorine $(1,4 \mathrm{or} 8 \mu \mathrm{mol} / \mathrm{l})$ at $37^{\circ} \mathrm{C}$ for $24 \mathrm{~h}$. Total protein was extracted from cells using RIPA lysate (Beyotime Institute 
A<smiles>O[C@H]1C=C2CCN3Cc4cc5c(cc4[C@H]([C@H]1O)[C@H]23)OCO5</smiles>

Lycorine

$\mathrm{C}_{16} \mathrm{H}_{17} \mathrm{NO}_{4}$

Molecular weight: 287.31

B

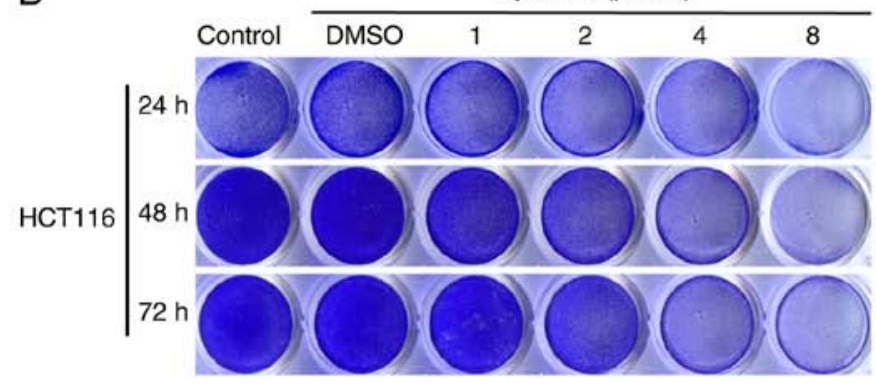

Lycorine $(\mu \mathrm{mol} / \mathrm{l})$

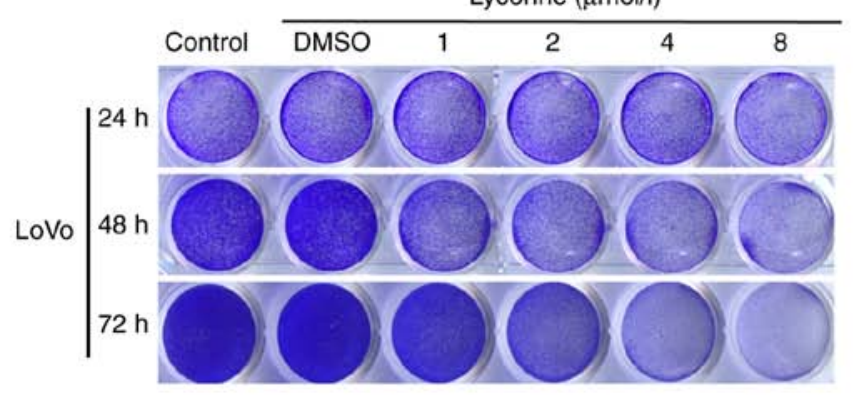

Lycorine $(\mu \mathrm{mol} / \mathrm{l})$

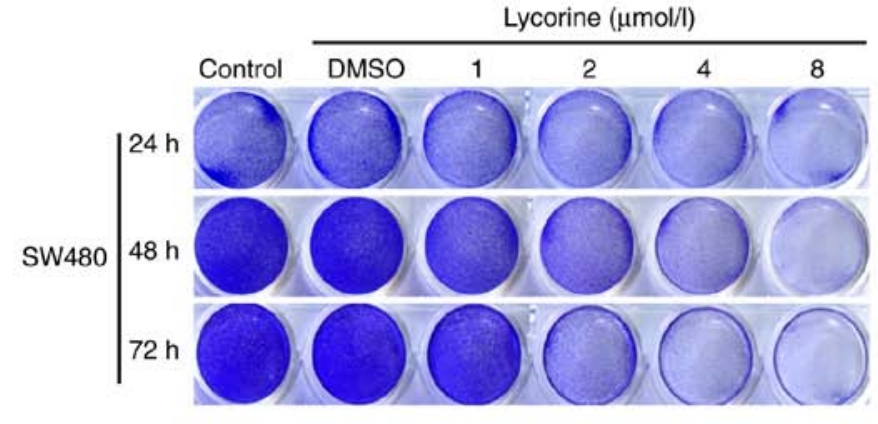

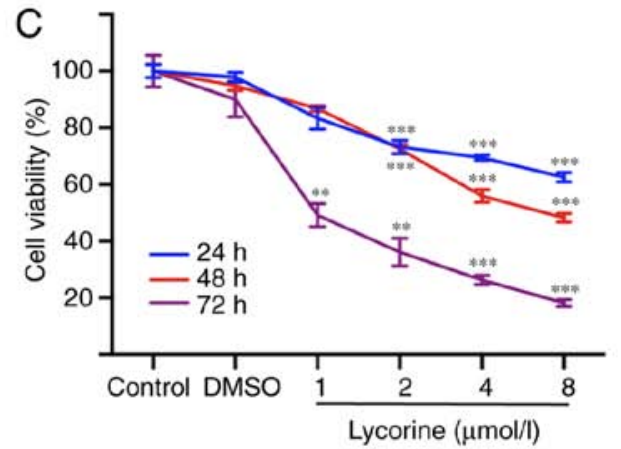
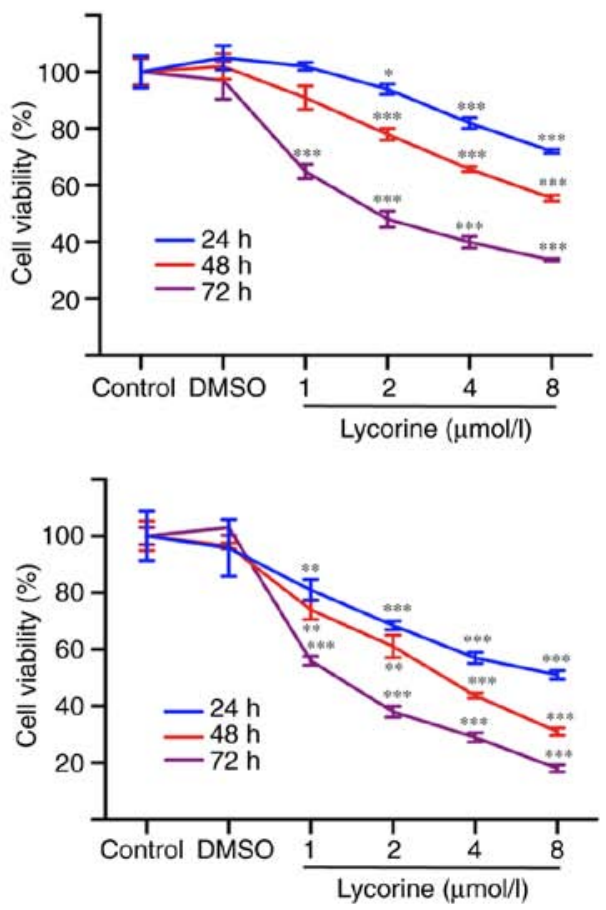

Figure 1. Effect of lycorine on CRC cell proliferation in vitro. (A) Chemical structure of lycorine. (B) Effect of lycorine on CRC cell proliferation as determined via crystal violet staining. (C) Effect of lycorine on CRC cell viability as determined via the MTT assay. Data are presented as the mean \pm SD ( $=3$ ). $P<0.05$, ${ }^{* *} \mathrm{P}<0.01$ and ${ }^{* * *} \mathrm{P}<0.001$ vs. Control. CRC, colorectal cancer.

of Biotechnology) supplemented with $1 \%$ protease inhibitors and phosphatase inhibitors (Roche Applied Science). Protein concentrations were determined using a BCA assay (Beyotime Institute of Biotechnology). Proteins $(35 \mu \mathrm{g})$ were separated via $10 \%$ SDS-PAGE (Beyotime Institute of Biotechnology) and subsequently transferred to PVDF membranes (EMD Millipore). Following blocking with 5\% BSA (Beijing Solarbio Science \& Technology Co., Ltd.) at $37^{\circ} \mathrm{C}$ for $2 \mathrm{~h}$, the membranes were incubated overnight at $4^{\circ} \mathrm{C}$ with primary antibodies, followed by incubation with the corresponding HRP-conjugated secondary antibodies at $37^{\circ} \mathrm{C}$ for $1 \mathrm{~h}$. Protein bands were visualized using an ChemiDoc $\mathrm{XRS}^{+}$enhanced chemiluminescence detection system (Bio-Rad Laboratories, Inc.). Protein expression levels were semi-quantified using ImageLab software (version 5.2.1; Bio-Rad Laboratories, Inc.). The primary and secondary antibodies used for western blotting are listed in Table SI.

Statistical analysis. Data are presented as the mean \pm SD of three independent experiments. Comparisons among groups were analyzed using one-way ANOVA followed by Bonferroni's post hoc test. Statistical analyses were performed using SPSS software (version 21.0; IBM Corp.). $\mathrm{P}<0.05$ was considered to indicate a statistically significant difference. 

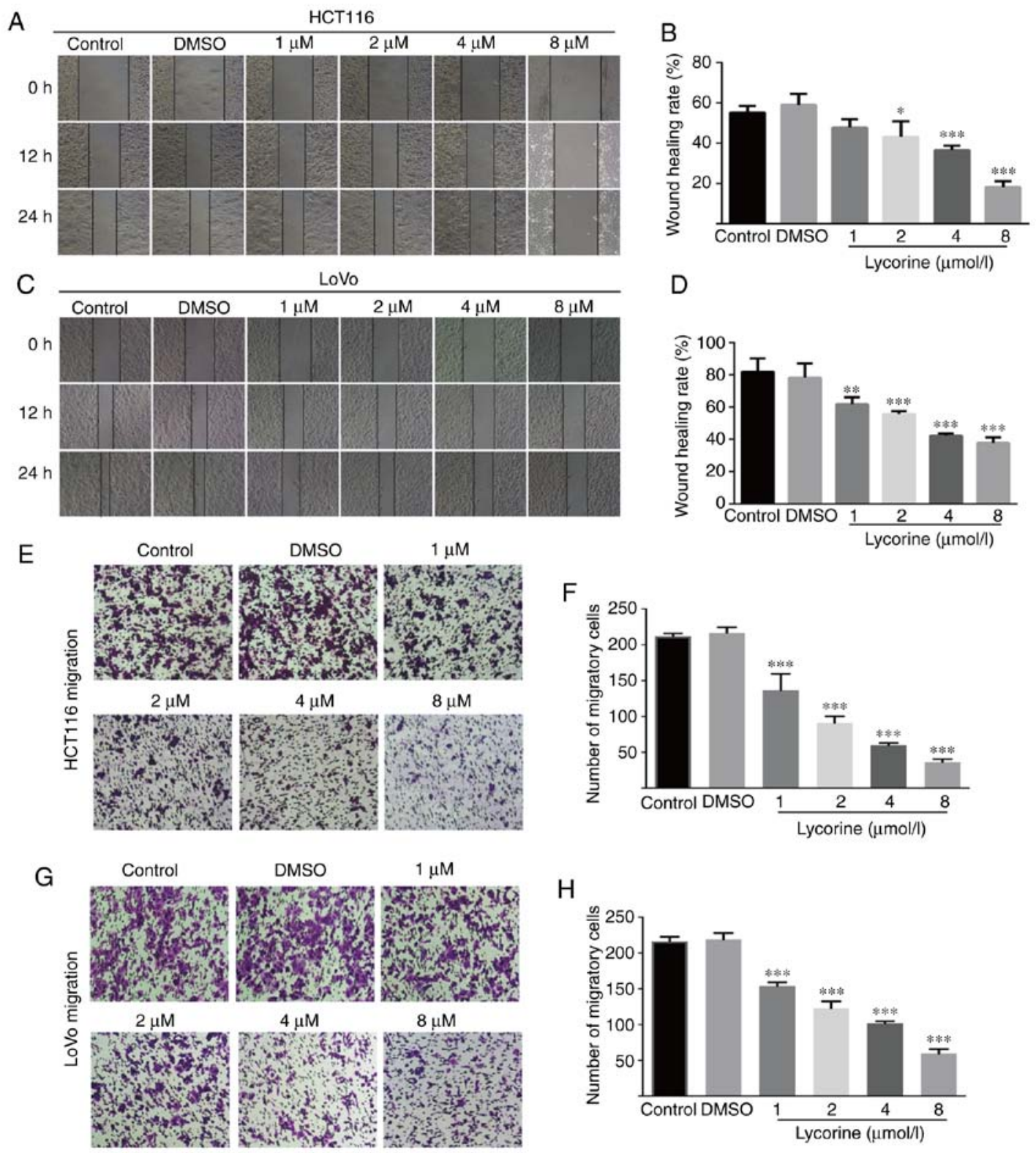

Figure 2. Effect of lycorine on CRC cell migration in vitro. Effect of lycorine on HCT116 cell migration was (A) determined by performing wound healing assays (magnification, $\mathrm{x} 100$ ) and (B) quantified. Effect of lycorine on LoVo cell migration was (C) determined by performing wound healing assays (magnification, $\mathrm{x} 100$ ) and (D) quantified. Effect of lycorine on HCT116 cell migration was (E) determined by performing Transwell migration assays (magnification, $\mathrm{x} 100$ ) and (F) quantified. Effect of lycorine on LoVo cell migration was (G) determined by performing Transwell migration assays (magnification, x100) and (H) quantified. Data are presented as the mean $\pm \mathrm{SD}(\mathrm{n}=3) .{ }^{*} \mathrm{P}<0.05,{ }^{* *} \mathrm{P}<0.01$ and ${ }^{* * *} \mathrm{P}<0.001$ vs. Control. CRC, colorectal cancer.

\section{Results}

Lycorine inhibits CRC cell proliferation. The chemical structure of lycorine is presented in Fig. 1A. Firstly, the effects of lycorine on human CRC cell proliferation were investigated. The crystal violet staining assay results demonstrated that lycorine suppressed cell proliferation in the three CRC cell lines in a dose- and time-dependent manner (Fig. 1B and C). Following treatment for $72 \mathrm{~h}$, the $\mathrm{IC}_{50}$ values of lycorine in HCT116, LoVo and SW480 cells were 1.4, 3.8 and $1.3 \mu \mathrm{mol} / 1$, respectively. The results indicated that HCT116 and LoVo cells were less sensitive to lycorine compared with the SW480 cell line; therefore, the HCT116 and LoVo cell lines were selected for subsequent experiments. The results suggested that lycorine inhibited CRC cell proliferation in vitro.
Lycorine decreases CRC cell migration and invasion. Wound healing assays are affected by cell migration and proliferation, and serum starvation is a common method used to minimize cell proliferation (10); however, the degree of cell tolerance in low-serum conditions should be taken into consideration. Therefore, wound healing and Transwell assays were performed to investigate lycorine treatment-mediated alterations to cell migration and invasion, respectively. Compared with the control group, lycorine $(\geq 2 \mu \mathrm{mol} / \mathrm{l})$ significantly reduced the wound healing rate of CRC cells (Fig. 2A-D). Also, lycorine $(\geq 4 \mu \mathrm{mol} / \mathrm{l}$ ) notably inhibited the wound healing rate of CRC cells to a similar extent at both 12 and $24 \mathrm{~h}$ (Fig. 2A and C). The aforementioned results suggested that lycorine inhibited CRC cell migration (Fig. 2A-D). The inhibitory effect of lycorine on CRC cell migration was further assessed by 

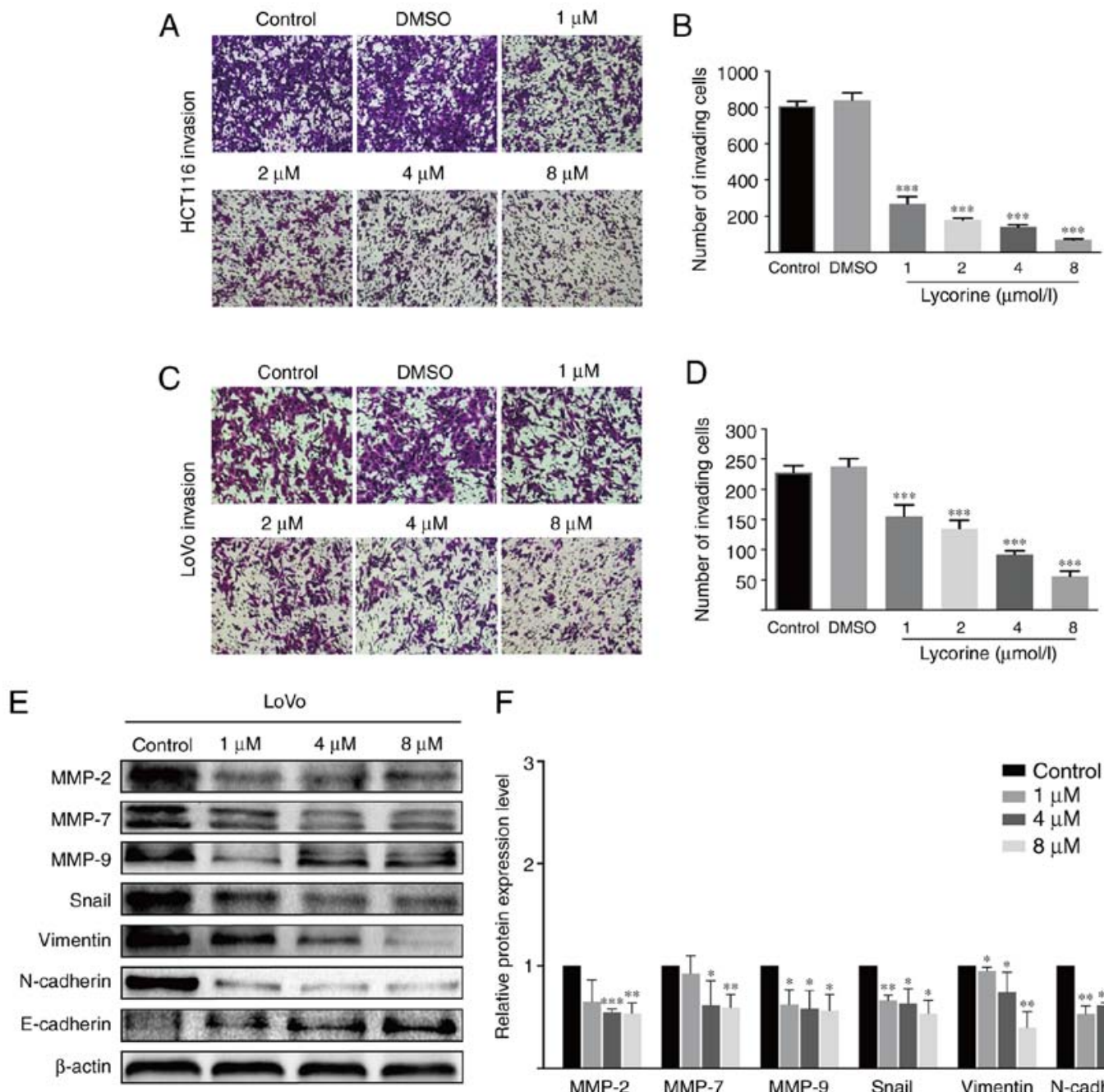

$\mathrm{F}$

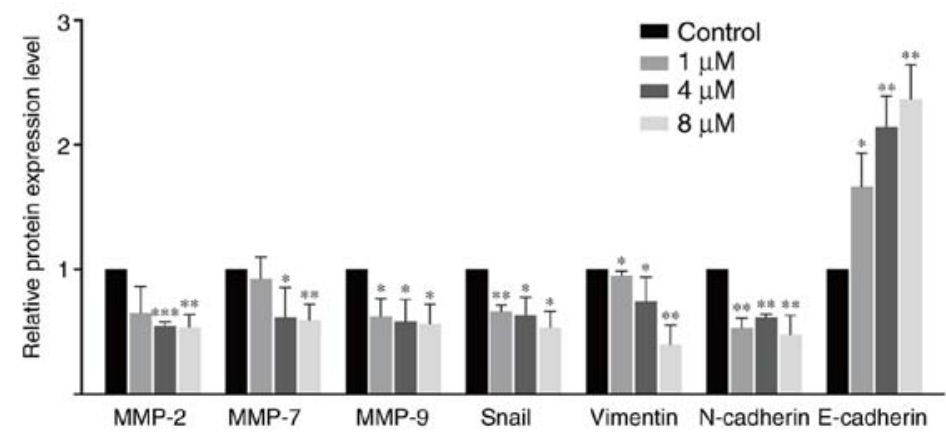

Figure 3. Effect of lycorine on CRC cell invasion in vitro. Effect of lycorine on HCT116 cell invasion was (A) determined by performing Transwell invasion assays (magnification, x100) and (B) quantified. Effect of lycorine on LoVo cell invasion was (C) determined by performing Transwell invasion assays (magnification, x100) and (D) quantified. Effect of lycorine on the protein expression levels of MMP-2, MMP-7, MMP-9, Snail, Vimentin, N-cadherin and E-cadherin in LoVo cells were (E) determined via western blotting and (F) semi-quantified. Data are presented as the mean $\pm \mathrm{SD}(\mathrm{n}=3) .{ }^{*} \mathrm{P}<0.05,{ }^{* *} \mathrm{P}<0.01$ and ${ }^{* * * *} \mathrm{P}<0.001$ vs. Control. CRC, colorectal cancer; MMP, matrix metallopeptidase; Snail, snail family transcriptional repressor 1.

performing Transwell assays (Fig. 2E-H). Moreover, the Transwell invasion assay results indicated that lycorine significantly decreased the number of invading CRC cells compared with the control group (Fig. 3A-D). The results suggested that lycorine attenuated CRC cell migration and invasion. Subsequently, western blotting was performed to evaluate the effect of lycorine on epithelial-mesenchymal transition (EMT) and extracellular matrix (ECM) degradation, which have been reported to serve essential roles in tumor cell migration and invasion $(11,12)$. Compared with HCT116 cells, the undifferentiated LoVo cell line displays a high EMT-signature, which might be a more representative mesenchymal phenotype (13). Therefore, in LoVo cells, compared with the control group, lycorine significantly decreased the protein expression levels of snail family transcriptional repressor 1 (Snail), Vimentin and $\mathrm{N}$-cadherin, which are EMT inducers $(11,14)$, but significantly increased the protein expression levels of E-cadherin, which is an anti-EMT molecule (14) (Fig. 3E). Moreover, the protein expression levels of ECM degradation markers, including MMP-2, MMP-7 and MMP-9, were significantly downregulated by lycorine $(\geq 4 \mu \mathrm{mol} / \mathrm{l})$ compared with the control group. Collectively, the results suggested that lycorine inhibited CRC cell migration and invasion.

Lycorine displays no obvious effect on CRC cell apoptosis. Hoechst 33258 staining was conducted to investigate whether lycorine altered HCT116 and LoVo cell apoptosis. Compared with the control group, karyopyknosis, karyorrhexis and apoptotic bodies were not increased by lycorine treatment (Fig. 4A and B). The flow cytometry results further demonstrated that lycorine did not significantly alter HCT116 and LoVo cell apoptosis compared with the control group. Moreover, the western blotting results indicated that the protein expression levels of antiapoptotic Bcl-2 were significantly decreased by lycorine ( $\geq 4 \mu \mathrm{mol} / \mathrm{l})$ treatment compared with the control group (Fig. 4G-J). Moreover, the protein expression levels of Caspase-3, an important downstream executor in the apoptosis cascade (15), and pro-apoptotic Bad and Bax were not significantly altered by lycorine treatment compared with the control group. The results indicated that lycorine-induced inhibition of proliferation was not associated with apoptosis in CRC cells. 


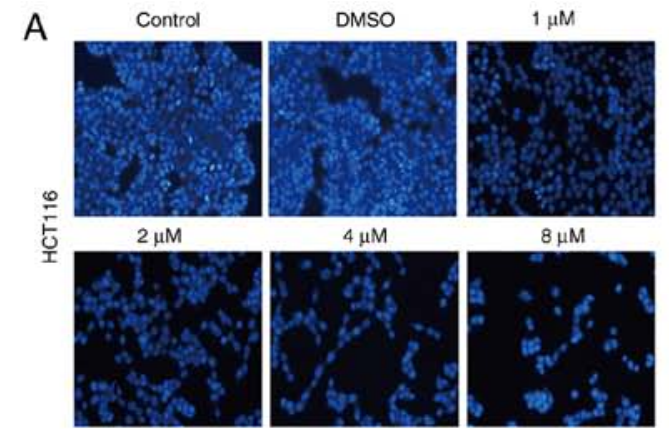

C

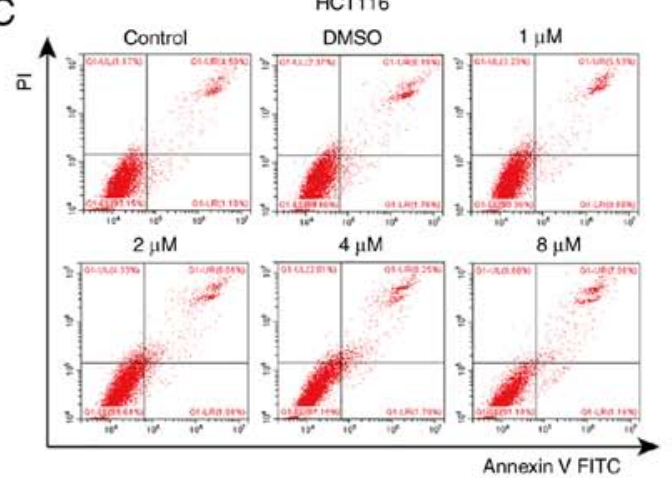

E

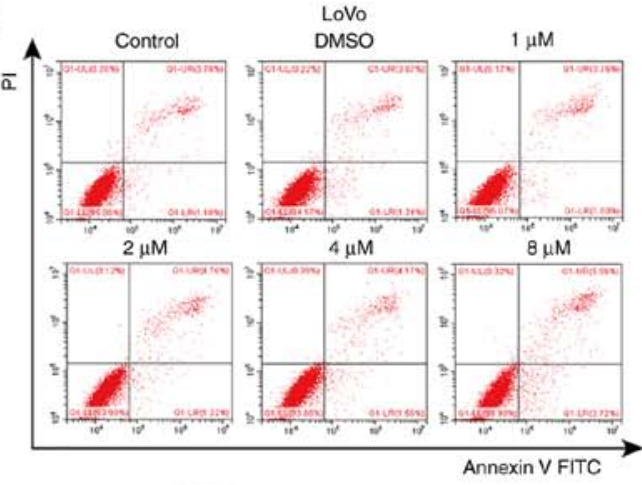

B

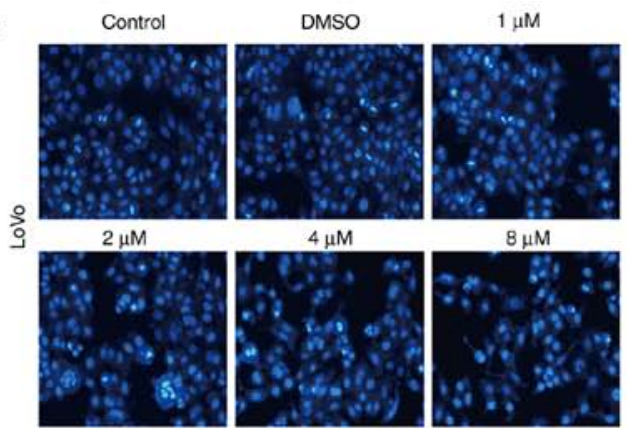

D

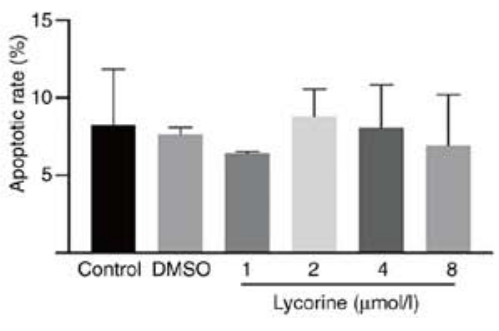

$\mathrm{F}$

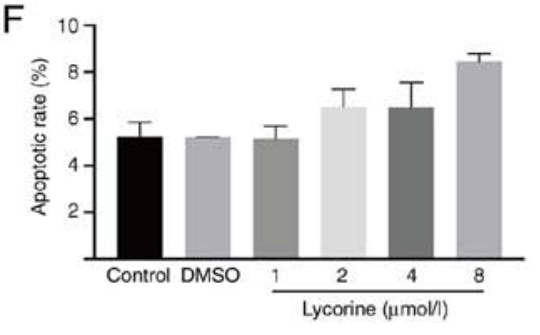

$\mathrm{G}$
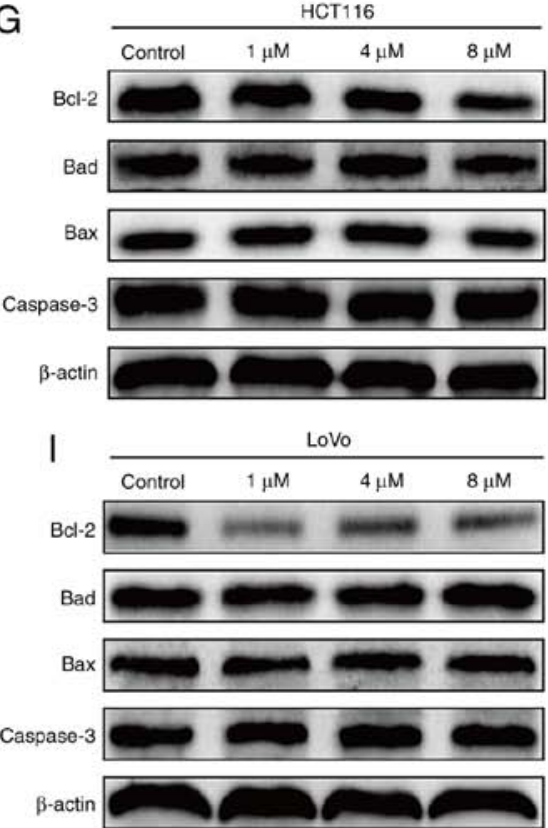

$\mathrm{H}$

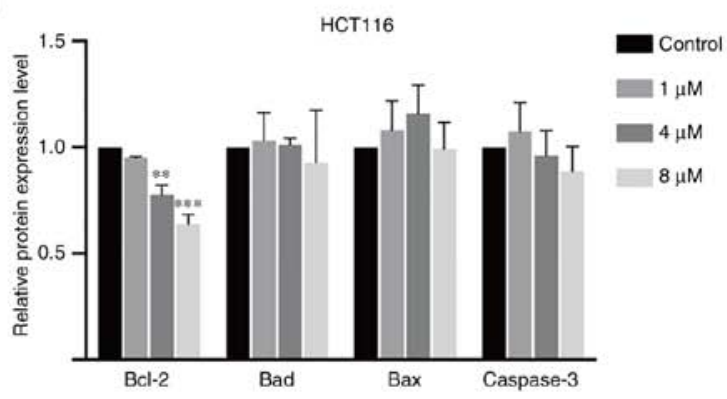

$J$

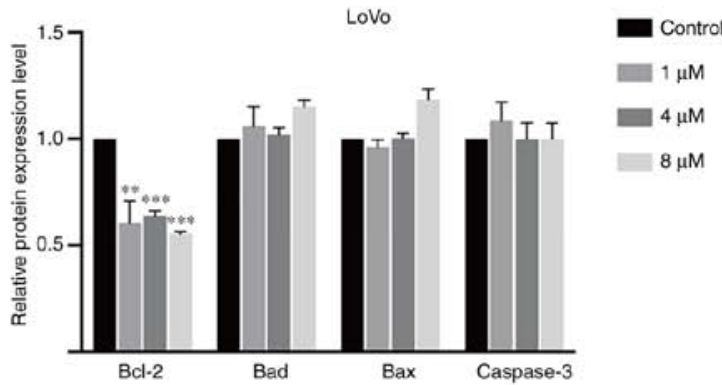

Figure 4. Effect of lycorine on CRC cell apoptosis in vitro. Effect of lycorine on (A) HCT116 and (B) LoVo cell apoptosis as determined via Hoechst 33258 staining (magnification, x200). Effect of lycorine on HCT116 cell apoptosis was (C) determined via flow cytometry and (D) quantified. Effect of lycorine on LoVo cell apoptosis was (E) determined via flow cytometry and (F) quantified. Effect of lycorine on HCT116 cell apoptosis was (G) determined via western blotting and (H) semi-quantified. Effect of lycorine on LoVo cell apoptosis was (I) determined via western blotting and (J) semi-quantified. Data are presented as the mean $\pm \mathrm{SD}(\mathrm{n}=3) .{ }^{* *} \mathrm{P}<0.01$ and ${ }^{* * * *} \mathrm{P}<0.001$ vs. Control. CRC, colorectal cancer. 
A

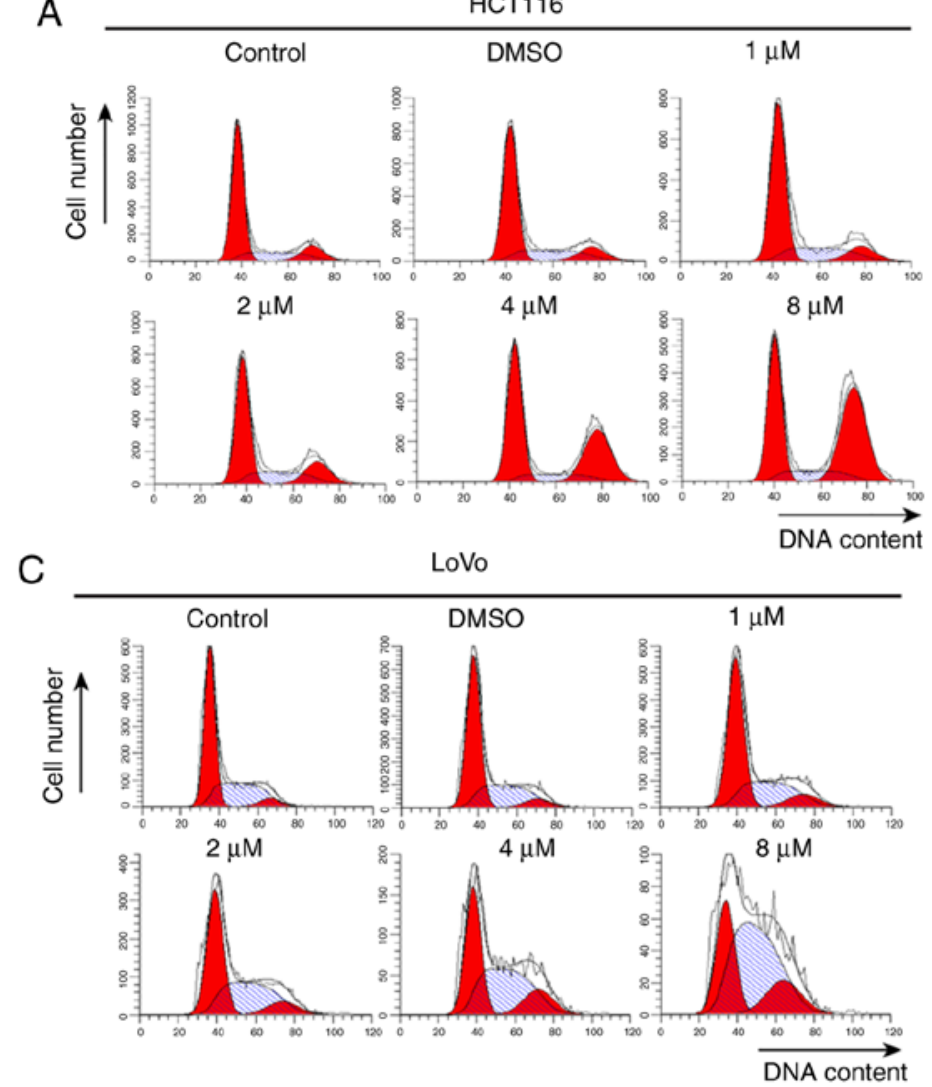

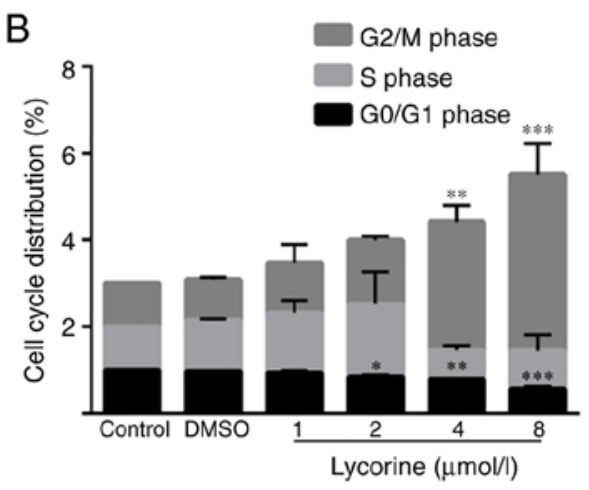

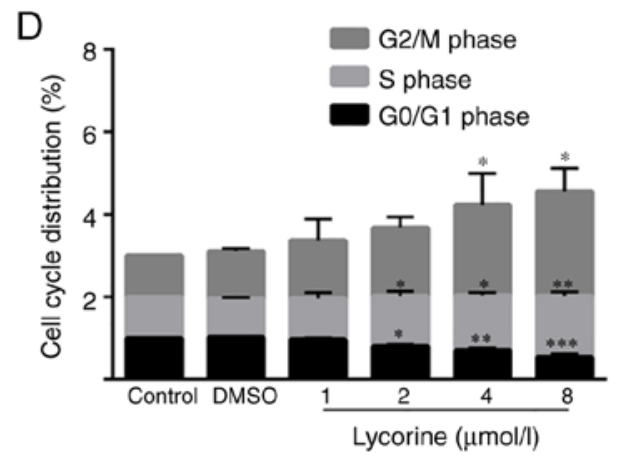

$\mathrm{E}$

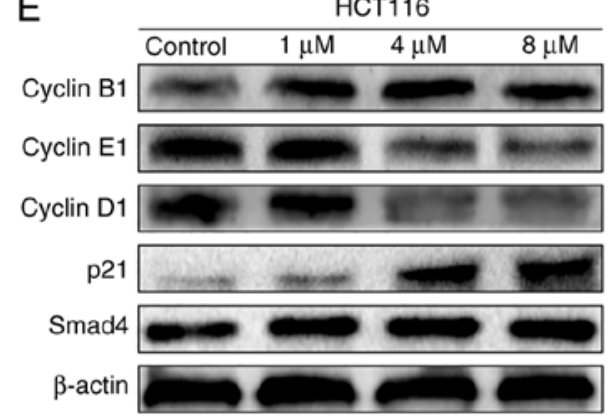

G

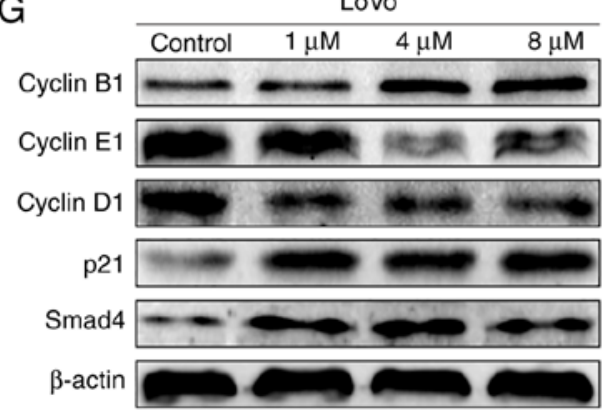

$\mathrm{F}$

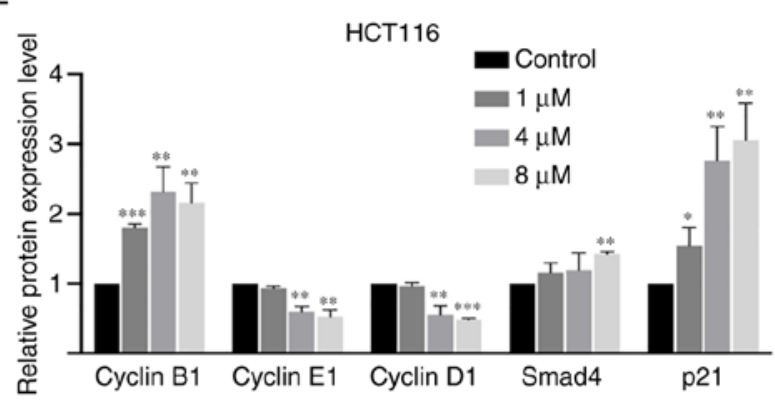

$\mathrm{H}$

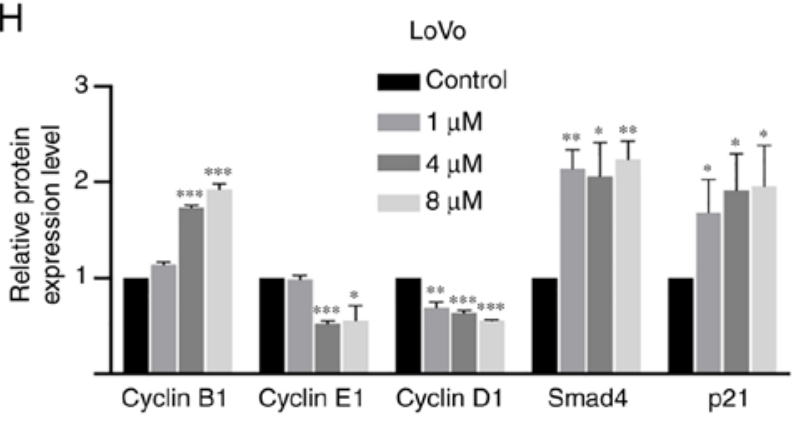

Figure 5. Effect of lycorine on cell cycle distribution in CRC cells in vitro. Effect of lycorine on cell cycle distribution in HCT116 cells was (A) determined via flow cytometry and (B) quantified. Effect of lycorine on cell cycle distribution in LoVo cells was (C) determined via flow cytometry and (D) quantified. Effect of lycorine on the protein expression levels of cyclin B1, cyclin E1, cyclin D1, p21 and Smad4 in HCT116 cells were (E) determined via western blotting and (F) semi-quantified. Effect of lycorine on the protein expression levels of cyclin B1, cyclin E1, cyclin D1, p21 and Smad4 in LoVo cells were (G) determined via western blotting and $(\mathrm{H})$ semi-quantified. Data are presented as the mean $\pm \mathrm{SD}(\mathrm{n}=3) .{ }^{*} \mathrm{P}<0.05,{ }^{* *} \mathrm{P}<0.01$ and ${ }^{* * * *} \mathrm{P}<0.001$ vs. Control. CRC, colorectal cancer.

Lycorine induces cell cycle arrest in CRC cell lines. As lycorine displayed no obvious effect on CRC cell apoptosis, it was hypothesized that lycorine might exert cytostasis to inhibit CRC cell proliferation. To investigate the hypothesis, flow cytometry was performed to determine the effect of lycorine on the cell cycle of CRC cells. Compared with the control group, lycorine treatment ( $\geq 4 \mu \mathrm{mol} / \mathrm{l})$ resulted in a significantly higher proportion of cells in the $\mathrm{G}_{2} / \mathrm{M}$ phase in HCT116 cells, but resulted in a significantly higher ratio of cells in the $\mathrm{S}$ and $\mathrm{G}_{2} / \mathrm{M}$ phases in LoVo cells (Fig. 5A-D). In 

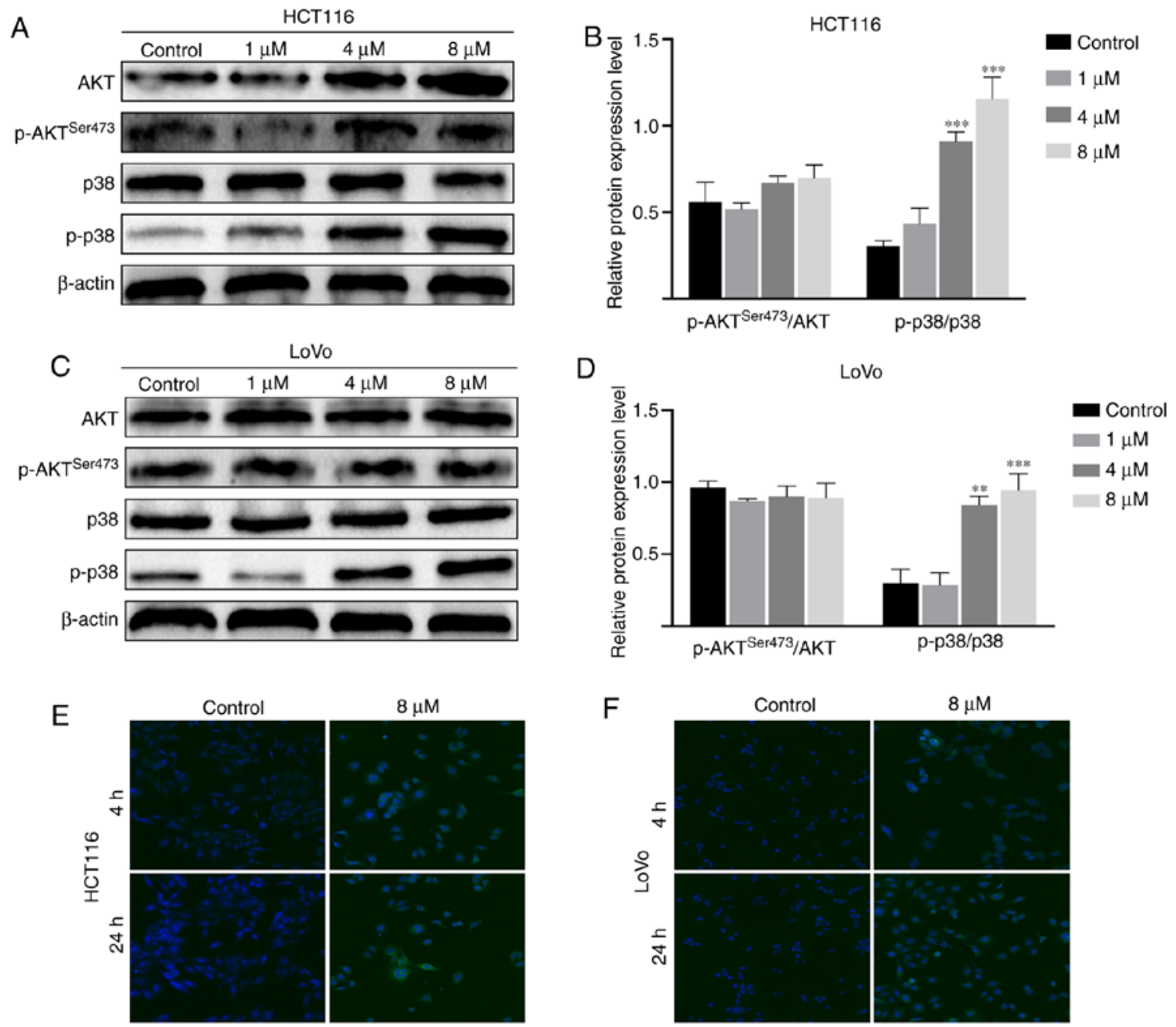

F
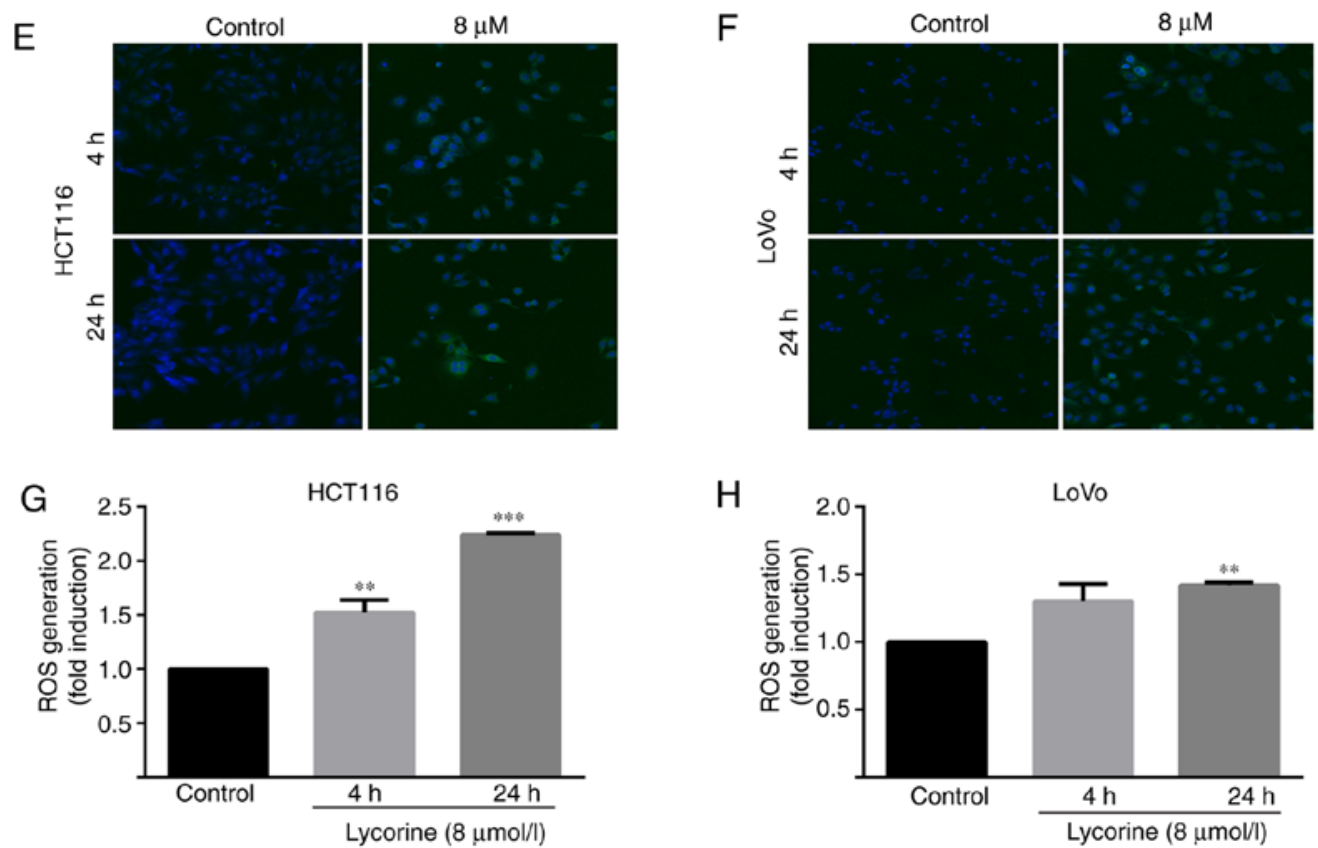

Figure 6. Effect of lycorine on AKT and ROS/p38 signaling pathways in CRC cells. Effect of lycorine on activation of the AKT signaling pathway in HCT116 cells was (A) determined via western blotting and (B) semi-quantified. Effect of lycorine on activation of the AKT signaling pathway in LoVo cells was (C) determined via western blotting and (D) semi-quantified. Effect of lycorine on ROS accumulation in (E) HCT116 and (F) LoVo cells as determined via confocal microscopy (magnification, x200). Effect of lycorine on ROS generation in (G) HCT116 and (H) LoVo cells as determined via DCFH-DA staining assay. Data are presented as the mean $\pm \mathrm{SD}(\mathrm{n}=3) .{ }^{* *} \mathrm{P}<0.01$ and ${ }^{* * *} \mathrm{P}<0.001$ vs. Control. ROS, reactive oxygen species; $\mathrm{CRC}$, colorectal cancer; $\mathrm{p}$, phosphorylated.

addition, the western blotting results indicated that compared with the control group, cyclin B1 expression levels were significantly increased, but cyclin D1 and cyclin E1 expression levels were significantly decreased by lycorine $(\geq 4 \mu \mathrm{mol} / \mathrm{l})$ in HCT116 and LoVo cells (Fig. 5E-H). Notably, the protein expression levels of cell cycle regulator p21 ( $\geq 1 \mu \mathrm{mol} / \mathrm{l})$ and Smad4 ( $8 \mu \mathrm{mol} / 1$ in HCT116 cells and $\geq 1 \mu \mathrm{mol} / 1$ in LoVo cells) were significantly upregulated by lycorine treatment compared with the control group. The results demonstrated that lycorine inhibited cell proliferation potentially via disrupting CRC cell progression.
Lycorine promotes the activation of $A K T$ and ROS/p 38 signaling pathways in CRC cells. Subsequently, the possible mechanism underlying lycorine-induced inhibitory effects against CRC cells were investigated. Compared with the control group, the protein expression level of phosphorylated-p38 was significantly increased by lycorine $(\geq 4 \mu \mathrm{mol} / \mathrm{l})$ in HCT116 and LoVo cells (Fig. 6A-D). Furthermore, compared with the control group, lycorine treatment significantly increased the levels of intracellular ROS in HCT116 (at 4 and $24 \mathrm{~h}$ ) and LoVo cells (at $4 \mathrm{~h}$ ) (Fig. 6E-H). The results suggested that lycorine might activate the ROS/p38 signaling pathway in CRC 


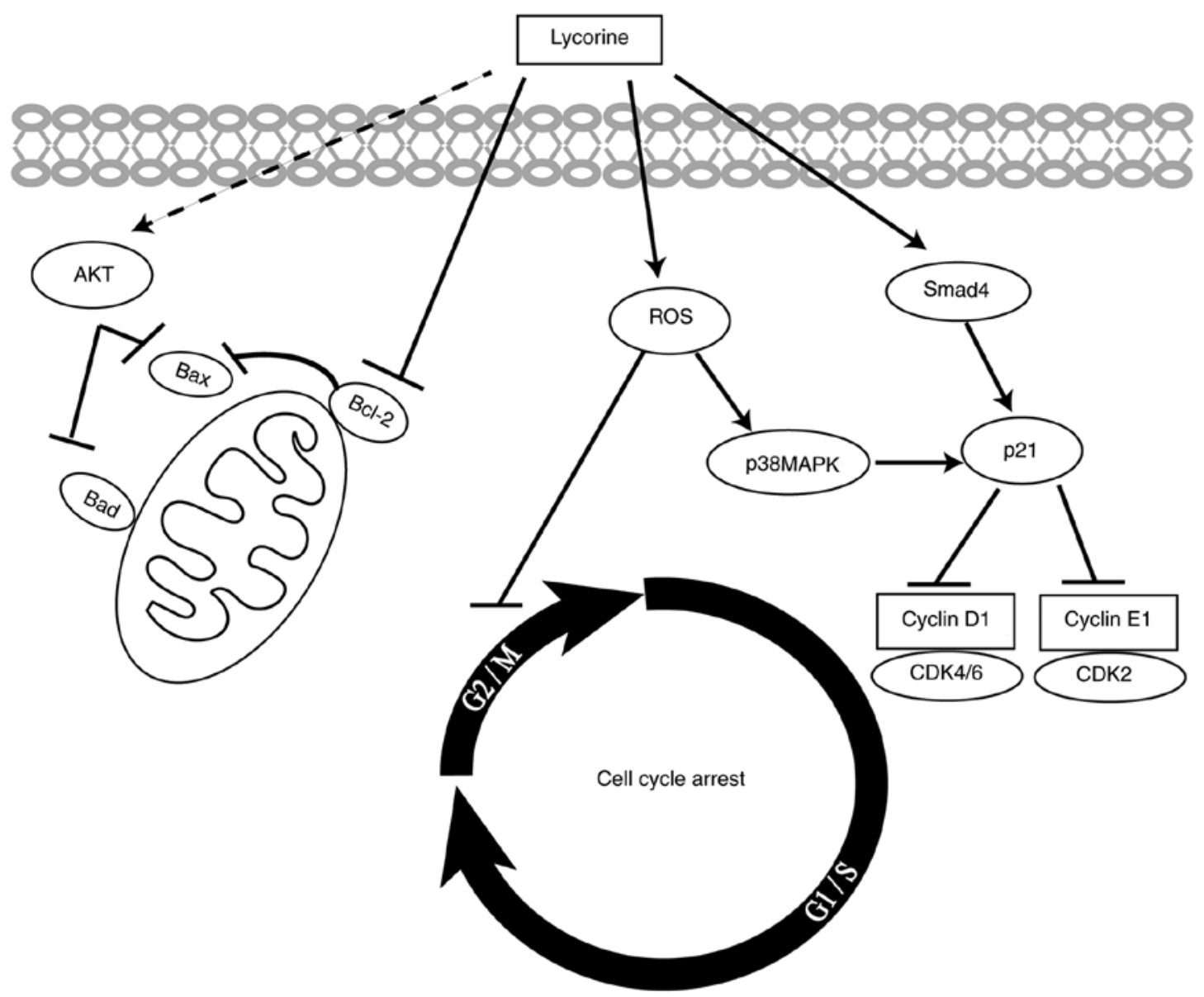

Figure 7. Proposed mechanism underlying lycorine-induced inhibitory effects on human CRC cells in vitro. CRC, colorectal cancer; ROS, reactive oxygen species.

cells. Moreover, compared with the control group, the protein expression levels of phosphorylated AKT and total AKT significantly increased by lycorine treatment $(\geq 4 \mu \mathrm{mol} / \mathrm{l})$ in HCT116 cells (Fig. 6C). Collectively, the results suggested that lycorine might enhance the activation of AKT and ROS/p38 signaling pathways in CRC cells.

\section{Discussion}

Colorectal cancer is a life-threatening tumor (1). Several drugs have been approved for the chemotherapy of CRC, and although these drugs display certain effects, patients typically develop drug resistance and the drugs display strong cytotoxicity against healthy cells and organs (16). For example, gastrointestinal (GI) toxicity as an adverse event exists universally in systemic therapy for CRC. Single 5-FU bolus or 5-FU-based combination chemotherapy can result in GI side effects (17). Moreover, 5-FU causes myelosuppression, hand-foot syndrome and cardiotoxicity $(18,19)$. Therefore, preoperative and postoperative adjuvant therapies for CRC treatment require the introduction of more effective and safer drugs. Lycorine is an alkaloid that is located in the bulbs of plant lycoris, and has been reported to effectively inhibit several types of cancer (6-9). In the present study, the anticancer effect of lycorine on CRC was investigated. Lycorine treatment inhibited cell proliferation in a dose- and time-dependent manner in the three CRC cell lines.
Moreover, the $\mathrm{IC}_{50}$ value of lycorine following $72 \mathrm{~h}$ treatment was $1.4 \mu \mathrm{mol} / 1$ in HCT116, which was similar to a previous study (20). Moreover, the results indicated that compared with the control group, lycorine significantly inhibited migration and invasion, but displayed no significant effect on CRC cell apoptosis.

MMPs serve vital roles in tumor metastasis via mediating ECM degradation (21). MMP-9, a widely studied MMP, is a potential cancer biomarker due to its involvement in numerous cancer-related processes, including cell migration, invasion, angiogenesis and inflammation (22). Additionally, epithelial tumor cells can obtain migratory and invading characteristics via the process of EMT (23). The LoVo cell line is a CRC cell line with a high degree of malignancy (13). The present study demonstrated that lycorine treatment significantly downregulated the protein expression levels of MMP-2, MMP-7 and MMP-9 in LoVo cells compared with the control group. Furthermore, compared with the control group, lycorine significantly increased the protein expression level of E-cadherin, an anti-EMT regulator, and significantly decreased the protein expression levels of Snail, Vimentin and $\mathrm{N}$-cadherin, which are pivotal EMT inducers. Collectively, the results suggested that lycorine inhibited CRC cell migration and invasion potentially via downregulating MMP protein expression levels and reversing the EMT process in CRC cells. 
Apoptosis is a highly regulated process of cellular death. There are two classic apoptosis signaling pathways: Extrinsic and intrinsic. The extrinsic apoptosis signaling pathway is initialized by the interaction between death receptors and TNF, Fas ligand or TNF superfamily member 10 ligand. By contrast, the intrinsic apoptosis signaling pathway refers to non-receptor-mediated initiation and mitochondrial regulation (24). The mechanism underlying lycorine-mediated apoptosis in tumors has been investigated. Previous studies revealed that lycorine induced apoptosis via a mitochondria-dependent apoptotic cascade or the death-receptor signaling pathway in tumor cells, including bladder cancer T24 cells (7), leukemia Mcl-1 cells (25) and HL-60 cells (26). In the present study, the Hoechst 33258 staining and flow cytometry results demonstrated that lycorine displayed no significant effect on HCT116 and LoVo cell apoptosis compared with the control group. Moreover, compared with the control group, lycorine significantly decreased the expression levels of Bcl-2, which displays an antiapoptotic effect by inhibiting Bax and blocking the process of mitochondrial outer membrane permeabilisation (27). However, the protein expression levels of Bad, Bax or the apoptosis effector caspase-3 were not significantly altered by lycorine treatment compared with the control group, which was consistent with the morphology and flow cytometry results. The results indicated that lycorine might primarily exert cytostatic effects rather than apoptosis inducing effects.

The AKT signaling pathway serves an important role in response to cell survival (28). Activation of the AKT signaling pathway may be related to the cytostatic effects of several anticancer drugs. For example, Richards et al (29) reported that Crassin, a Diterpenoid natural compound against cancer cells, induced cytostatic effects via activating the AKT signaling pathway and then promoting ROS activation in triple-negative breast cancer cells. Goyeneche et al (30) and Wempe et al (31) reported that AKT signaling was activated to exert cytostatic effects on ovarian cancer cells in mifepristone-induced antitumor activity. The western blotting results indicated that $\mathrm{AKT}$ activation might serve a role in the cytostatic effect of lycorine against CRC cells. Moreover, whether lycorine in combination with AKT inhibitors could inhibit the cytostatic effect of lycorine on CRC cells requires further investigation.

Previous studies have demonstrated that $5 \mu \mathrm{M}$ lycorine reduced mitosis in glioblastoma U373 cells and non-small-cell lung cancer A549 cells by $>90 \%$ without inducing cell apoptosis $(9,32)$, which suggested that lycorine may display strong inhibitory effects on cancer, especially in those naturally resistant to proapoptotic stimuli. In the present study, based on the finding that lycorine did not alter apoptosis, it was hypothesized that lycorine may primarily exert cytostatic effects by regulating the cell cycle in CRC cells. The flow cytometry results supported this hypothesis, demonstrating that lycorine significantly induced cell cycle arrest at the $\mathrm{G}_{2} / \mathrm{M}$ phase in HCT116 cells, and at the $\mathrm{S}$ and $\mathrm{G}_{2} / \mathrm{M}$ phase in LoVo cells compared with the control group. Cancer cells display cell cycle dysregulation, resulting in unscheduled and rapid cell division, which is a hallmark of tumors (33). The cell cycle is controlled by a subfamily of CDKs complexed with cyclin proteins (34). Aberrations of CDKs drive re-entry into the cell cycle in cancer cells (35); therefore, inducing cell cycle arrest via activation of checkpoints to modulate CDK activity may serve as an effective therapeutic strategy. For example, targeting the cyclin D1-Cdk4/6 complex as a therapeutic invention has been focused on due to the invariable deregulation of the complex in human tumors (36). CDK4/6 inhibitors are already available for clinical use in the USA (37). Meanwhile, in the present study, compared with the control group, lycorine significantly downregulated the protein expression levels of cyclin D1 and cyclin E1 in HCT116 and LoVo cells. p21 is a negative regulator of the cell cycle that functions by dampening the activity of cyclin-CDK complexes (38). The results of the present study indicated that the protein expression levels of p21 were significantly increased by lycorine treatment compared with the control group. In CRC, Smad4 serves a tumor-suppressing role by controlling a cohort of targeting genes, including p21, to trigger cell cycle arrest at the $G_{1} / S$ phase (39). It has been reported that Smad4 expression was absent in $20-40 \%$ of cases, which promotes tumor progression and is associated with poor prognosis (40). The present study demonstrated that lycorine significantly upregulated the protein expression levels of Smad4 compared with the control group. Collectively, the results indicated that lycorine exerted anti-CRC effects potentially via triggering cell cycle arrest in CRC cells.

p38 belongs to the MAPK family and is involved in cell proliferation, migration, differentiation and apoptosis $(41,42)$. The roles of p38 in occurrence and development of cancer have been previously investigated (43); however, the obtained results are controversial, with certain studies suggesting a stimulatory role of p38 in cancer and others proposing an inhibitory role of $\mathrm{p} 38$. A recent study demonstrated that $\mathrm{p} 38$ interfered with initial steps of colorectal adenomagenesis, and nuclear p38 was correlated with low-grade dysplasia and decreased adenoma size (44). The results of the present study demonstrated that lycorine promoted activation of the p38 signaling pathway, leading to increased p38 phosphorylation in CRC cells compared with the control group. Therefore, the mechanism underlying p38 activation was investigated. p38 can be activated by several stimuli, such as inflammatory factors, DNA damage and ROS (42). ROS serves pivotal roles in cell physiology and participates in several pathological processes. When ROS generation exceeds the antioxidant capacity of the cell, cells enter an oxidative stress state, causing cell dysfunction and behavioral alterations, including cell cycle arrest, senescence and cell death (45). Therefore, it was hypothesized that p38 activation may be a consequence of ROS generation. To verify whether lycorine affected ROS accumulation, a DCFH-DA staining assay was performed. The results demonstrated that ROS intracellular levels in HCT116 and LoVo cells were increased by lycorine treatment compared with the control group. Therefore, lycorine-induced antitumor effects might be closely related to ROS/p38 signaling.

In conlusion, the present study demonstrated that lycorine suppressed CRC cell proliferation, migration and invasion and cell cycle progression in vitro. Moreover, to the best of our knowledge, the present study was the first to suggest that lycorine exerted cytostatic effects on CRC cells via ROS/p38 and AKT signaling pathways (Fig. 7). Therefore, the results of the present study suggested that lycorine might serve as a therapeutic for CRC. Future studies should investigate the 
correlation between ROS accumulation and p38 activation, as well as the potential of lycorine in combination with other drugs in CRC treatment.

\section{Acknowledgements}

Not applicable.

\section{Funding}

The present study was supported by the National Natural Science Foundation of China (grant no. 81874001) and the Scientific Research and Technology Development Program of Chongqing (grant no. cstc2017jcyjAX0196).

\section{Availability of data and materials}

The datasets used and/or analyzed during the current study are available from the corresponding author on reasonable request.

\section{Authors' contributions}

JL, PZ, XY, TY, HH, CY, LZ, SY and XL made substantial contributions to the study design. JL and XL critically revised the manuscript for important intellectual content. PZ drafted the manuscript, and agreed to be accountable for the work in ensuring that questions related to the integrity of any part of the work are appropriately investigated and resolved. PZ, CY, LZ and SY acquired the data. XY, TY and HH analyzed and interpreted the data. All authors read and approved the final manuscript.

\section{Ethics approval and consent to participate}

Not applicable.

\section{Patient consent for publication}

Not applicable.

\section{Competing interests}

The authors declare that they have no competing interests.

\section{References}

1. Bray F, Ferlay J, Soerjomataram I, Siegel RL, Torre LA and Jemal A: Global cancer statistics 2018: GLOBOCAN estimates of incidence and mortality worldwide for 36 cancers in 185 countries. CA Cancer J Clin 68: 394-424, 2018.

2. Wild CP, Weiderpass E, Stewart BW, editors (2020). World Cancer Report: Cancer Research for Cancer Prevention. Lyon, France: International Agency for Research on Cancer. http://publications.iarc.fr/586.

3. Brenner H, Kloor M and Pox CP: Colorectal cancer. Lancet 383: 1490-1502, 2014.

4. Mohammed AA, El-Tanni H, El-Khatib HM, Mirza AA and El-Kashif AT: WITHDRAWN: Molecular classification of colorectal cancer: Current perspectives and controversies. J Egypt Natl Canc Inst: Jan 2, 2016 (Epub ahead of print). doi: 10.1016/j.jnci.2015.11.004.

5. Kaya GI, Cicek D, Sarikaya B, Onur MA and Somer NU: HPLC DAD analysis of lycorine in Amaryllidaceae species. Nat Prod Commun 5: 873-876, 2010.
6. Luo Y, Roy M, Xiao X, Sun S, Liang L, Chen H, Fu Y, Sun Y, Zhu M, Ye M and Liu J: Lycorine induces programmed necrosis in the multiple myeloma cell line ARH-77. Tumour Biol 36: 2937-2945, 2015

7. Wang C, Wang Q, Li X, Jin Z, Xu P, Xu N, Xu A, Xu Y, Zheng S, Zheng J, et al: Lycorine induces apoptosis of bladder cancer T24 cells by inhibiting phospho-AKT and activating the intrinsic apoptotic cascade. Biochem Biophys Res Commun 483: 197-202, 2017.

8. Ying X, Huang A, Xing Y, Lan L, Yi Z and He P: Lycorine inhibits breast cancer growth and metastasis via inducing apoptosis and blocking Src/FAK-involved pathway. Sci China Life Sci 60: 417-428, 2017.

9. Lamoral-Theys D, Andolfi A, Van Goietsenoven G, Cimmino A Le Calvé B, Wauthoz N, Mégalizzi V, Gras T, Bruyère C, Dubois J, et al: Lycorine, the main phenanthridine amaryllidaceae alkaloid, exhibits significant antitumor activity in cancer cells that display resistance to proapoptotic stimuli: An investigation of structure-activity relationship and mechanistic insight. J Med Chem 52: 6244-6256, 2009.

10. Davis PK, Ho A and Dowdy SF: Biological methods for cell-cycle synchronization of mammalian cells. Biotechniques 30: 1322-1331, 2001

11. Nieto MA, Huang RY, Jackson RA and Thiery JP: EMT: 2016. Cell 166: 21-45, 2016.

12. Yuzhalin AE, Lim SY, Kutikhin AG and Gordon-Weeks AN: Dynamic matrisome: ECM remodeling factors licensing cancer progression and metastasis. Biochim Biophys Acta Rev Cancer 1870: 207-228, 2018.

13. Berg KCG, Eide PW, Eilertsen IA, Johannessen B, Bruun J, Danielsen SA, Bjørnslett M, Meza-Zepeda LA, Eknæs M, Lind GE, et al: Multi-omics of 34 colorectal cancer cell lines-a resource for biomedical studies. Mol Cancer 16: 116, 2017.

14. Serrano-Gomez SJ, Maziveyi M and Alahari SK: Regulation of epithelial-mesenchymal transition through epigenetic and post-translational modifications. Mol Cancer 15: 18, 2016.

15. Porter AG and Jänicke RU: Emerging roles of caspase-3 in apoptosis. Cell Death Differ 6: 99-104, 1999.

16. Meyers BM, Cosby R, Quereshy F and Jonker D: Adjuvant chemotherapy for stage II and III colon cancer following complete resection: A cancer care ontario systematic review. Clin Oncol (R Coll Radiol) 29: 459-465, 2017.

17. Lee CS, Ryan EJ and Doherty GA: Gastro-intestinal toxicity of chemotherapeutics in colorectal cancer: The role of inflammation. World J Gastroenterol 20: 3751-3761, 2014.

18. Zhang L, Xing X, Meng F, Wang Y and Zhong D: Oral fluoropyrimidine versus intravenous 5-fluorouracil for the treatment of advanced gastric and colorectal cancer: Meta-analysis. J Gastroenterol Hepatol 33: 209-225, 2018.

19. Abdel-Rahman O: 5-Fluorouracil-related cardiotoxicity; findings from five randomized studies of 5-fluorouracil-based regimens in metastatic colorectal cancer. Clin Colorectal Cancer 18: 58-63, 2019.

20. Wang P, Yuan HH, Zhang X, Li YP, Shang LQ and Yin Z: Novel lycorine derivatives as anticancer agents: Synthesis and in vitro biological evaluation. Molecules 19: 2469-2480, 2014.

21. Winer A, Adams S and Mignatti P: Matrix metalloproteinase inhibitors in cancer therapy: Turning past failures into future successes. Mol Cancer Ther 17: 1147-1155, 2018.

22. Huang H: Matrix metalloproteinase-9 (MMP-9) as a cancer biomarker and MMP-9 biosensors: Recent advances. Sensors (Basel) 18: 3249, 2018.

23. Bates RC and Mercurio AM: The epithelial-mesenchymal transition (EMT) and colorectal cancer progression. Cancer Biol Ther 4: 365-370, 2005.

24. Elmore S: Apoptosis: A review of programmed cell death. Toxicol Pathol 35: 495-516, 2007.

25. Liu XS, Jiang J, Jiao XY, Wu YE, Lin JH and Cai YM: Lycorine induces apoptosis and down-regulation of Mcl-1 in human leukemia cells. Cancer Lett 274: 16-24, 2009.

26. Liu J, Hu JL, Shi BW, He Y and Hu WX: Up-regulation of p21 and TNF-alpha is mediated in lycorine-induced death of HL-60 cells. Cancer Cell Int 10: 25, 2010.

27. Siddiqui WA, Ahad A and Ahsan H: The mystery of BCL2 family: Bcl-2 proteins and apoptosis: An update. Arch Toxicol 89: 289-317, 2015.

28. Song G, Ouyang G and Bao S: The activation of Akt/PKB signaling pathway and cell survival. J Cell Mol Med 9: 59-71, 2005.

29. Richards CE, Vellanki SH,Smith YE and Hopkins AM: Diterpenoid natural compound $\mathrm{C} 4$ (Crassin) exerts cytostatic effects on triple-negative breast cancer cells via a pathway involving reactive oxygen species. Cell Oncol (Dordr) 41: 35-46, 2018. 
30. Goyeneche AA, Carón RW and Telleria CM: Mifepristone inhibits ovarian cancer cell growth in vitro and in vivo. Clin Cancer Res 13: 3370-3379, 2007.

31. Wempe SL, Gamarra-Luques CD and Telleria CM: Synergistic lethality of mifepristone and LY294002 in ovarian cancer cells. Cancer Growth Metastasis 6: 1-13, 2013.

32. Van Goietsenoven G, Andolfi A, Lallemand B, Cimmino A, Lamoral-Theys D, Gras T, Abou-Donia A, Dubois J, Lefranc F, Mathieu V, et al: Amaryllidaceae alkaloids belonging to different structural subgroups display activity against apoptosis-resistant cancer cells. J Nat Prod 73: 1223-1227, 2010.

33. Malumbres $M$ and Barbacid M: To cycle or not to cycle: A critical decision in cancer. Nat Rev Cancer 1: 222-231, 2001.

34. Schafer KA: The cell cycle: A review. Vet Pathol 35: 461-478, 1998.

35. Malumbres $M$ and Barbacid M: Cell cycle, CDKs and cancer: A changing paradigm. Nat Rev Cancer 9: 153-166, 2009.

36. O'Leary B, Finn RS and Turner NC: Treating cancer with selective CDK4/6 inhibitors. Nat Rev Clin Oncol 13: 417-430, 2016.

37. Goel S, DeCristo MJ, McAllister SS and Zhao JJ: CDK4/6 inhibition in cancer: Beyond cell cycle arrest. Trends Cell Biol 28: 911-925, 2018

38. Abbas T and Dutta A: p21 in cancer: Intricate networks and multiple activities. Nat Rev Cancer 9: 400-414, 2009.
39. Zhao M, Mishra L and Deng CX: The role of TGF- $\beta /$ SMAD4 signaling in cancer. Int J Biol Sci 14: 111-123, 2018.

40. Salovaara R, Roth S, Loukola A, Launonen V, Sistonen P, Avizienyte E, Kristo P, Järvinen H, Souchelnytskyi S, Sarlomo-Rikala $M$ and Aaltonen LA: Frequent loss of SMAD4/DPC4 protein in colorectal cancers. Gut 51: 56-59, 2002.

41. Cuenda A and Sanz-Ezquerro JJ: p38 $\gamma$ and p388: From spectators to key physiological players. Trends Biochem Sci 42: 431-442, 2017.

42. Bonney EA: Mapping out p38MAPK. Am J Reprod Immunol 77: e12652, 2017.

43. Martínez-Limón A, Joaquin M, Caballero M, Posas F and de Nadal E: The p38 pathway: From biology to cancer therapy. Int J Mol Sci 21: 1913, 2020.

44. Handra-Luca A, Bendib M and Magkou C: P38 expression in colorectal adenomas: Relationships to cell proliferation, stem phenotype and akt pathway proteins. Minerva Gastroenterol Dietol 66: 208-210, 2020.

45. Moloney JN and Cotter TG: ROS signalling in the biology of cancer. Semin Cell Dev Biol 80: 50-64, 2018.

This work is licensed under a Creative Commons Attribution-NonCommercial-NoDerivatives 4.0 International (CC BY-NC-ND 4.0) License. 